DOI https://doi.org/10.30525/978-9934-26-180-0-2

\title{
ДЕВІАНТНІ ДЕРИВАЦІЙНІ РЕПРЕЗЕНТАНТИ У ФОКУСІ ПСИХОЛІНГВІСТИЧНИХ ТЕОРІЙ ЯК ОБ'ЄКТ МОВОЗНАВЧОГО СТУДІЮВАННЯ
}

\author{
Дюкар К. В. \\ кандидатка філологічних наук, \\ доцент кафедри української мови \\ Харківський національний університет імені В. Н. Каразіна \\ м. Харків, Україна
}

Наразі загальновизнаним фактом $є$ те, що мозок людини працює на надзвичайно високих швидкостях унаслідок великих обсягів опрацьовуваної інформації, потік якої не зупиняється, а навпаки, пришвидшується й розширюється. У глобалізованому інфопотоці мовець часто відчуває, із одного боку, об'єктивний брак номінативних одиниць, максимальною мірою адаптованих до національного мовного коду як із погляду змісту, так і з погляду форми, а 3 другого - потребу в повторній вербалізації понять із власних суб'єктивних міркувань. Незалежно від причин пошуку засобів і способів реалізації в комунікативному акті номінативного складника, ключова роль у цьому процесі відведена граматичному оформленню мовлення, зокрема словотворенню й формотворенню, що дають змогу декодовувати висловлення різних ступенів прозорості та герметичності смислів, отже сприймати та відтворювати ці вербальні фрагменти надалі. Із огляду на це особливий інтерес становить не лише сама природа мовлення як матеріалізація мислення, як репрезентація тих процесів, що вони відбуваються на рівні свідомості чи підсвідомості, а й механізми та закономірності формування, коригування й актуалізування бази словотвірних кліше залежно від потреб конкретного комунікативного акту.

В аналогічному чи подібному вигляді поставлені вище питання цікавлять академічну спільноту з початку XIX століття. Підгрунтя наукового вивчення проблеми закладене В. фон Гумбольдтом, який, диференціювавши мову й мовлення, намагався пояснити природу їхнього зв'язку з мисленням. Називаючи такий підхід метафізичним, І. Бодуен де Куртене наголошував на психічній природі мови й апелював до реальності мозкової діяльності, утіленням якої є мова індивідуума. Крім того, учений уперше виділив морфему як одиницю по суті психологічного рівня. Ф. де Соссюр доводив виняткове значення аналогії для перебігу словотвірних 12 
процесів у мовленні й наполягав, що деривація здійснюється не в момент появи слова, оскільки окремі складники останнього вже наявні в підсвідомості мовця, і $є$ наслідком нескладної розумової операції, подібної до обчислення. Фактично вчений виходив на психолінгвістичний рівень обгрунтування мовленнєвих явищ і їхньої перспективи інтегрування в мовну систему. Ідеї дослідника набули розвитку в працях Л. Щерби, наукові пошуки якого, зокрема в царині словотвору, на початкових етапах відбувалися в межах панівних на той час психологічних концепцій. Саме завдяки дослідникові в науковому обігу з'явилося поняття «психофізіологічна мовленнєва організація індивіда», що вона формується й реалізується завдяки мовленнєвому досвіду. Основоположником психологічного напряму у вітчизняній лінгвістиці називають О. Потебню, останні праці 3 лексикології якого більшою мірою стосувалися різних аспектів слов'янського словотвору. Попри розбіжності в поглядах на зв'язок і взаємодію елементів тріади «мислення - мовлення - мова», дослідники наближалися до розуміння того, що йдеться про складні психофізіологічні процеси, що вони супроводжують не лише мову, а й окремі акти мовлення та розуміння цього мовлення. Оформивши цю думку, О. Дитріх підняв питання щодо потреби ввести психологію мови як окрему наукову дисципліну. 1913 року Ф. Кайнц у роботі «Психологія мови» реалізує таку ідею, намагаючись виробити чітке теоретико-методологічне підгрунтя психологічного аналізу лінгвістичних явищ. Усебічно й докладно еволюцію різних напрямів психолінгвістичних студій висвітлено в працях О. Леонтьєва, який і сам 3-поміж іншого вивчав психологічні засади деривації. Зі створення 1958 р. Сектору психолінгвістики й теорії масової комунікації Інституту мовознавства СРСР активізуються студії, пов'язані 3 концепцією «психологічної реальності словотвірних процесів». Додамо, що після набуття Україною статусу незалежної держави вітчизняний науковий поступ у цій сфері дещо загальмувався, тоді як за кордоном, особливо в Свропі, він, навпаки, набував усе більшої популярності.

Із розгалуженням психолінгвістики як науки на окремі напрями можемо констатувати стабільний інтерес учених, переважно зарубіжних, до вивчення різних аспектів психолінгвістичної природи мовлення людини, зокрема словотворчості, у межах мультидисциплінарних студій. Варто наголосити, що українські лінгвістики лише протягом останнього десятиліття зробили поодинокі спроби дослідити цю тематику. Так, А. Загнітко, розглядаючи сучасні лінгвістичні теорії в комплексі, звертається й до загальних уявлень про психолінгвістичні аспекти словотвору і граматики. Узагальнюючи погляди психолінгвістів, учений 
зосереджується переважно на творенні нових слів на позначення відомих мовцеві понять за допомогою високопродуктивного дериваційного інструментарію через аналогії до часто відтворюваних індивідом граматичних конструкцій [4, с. 77]. У цьому контексті дослідник актуалізує поняття «народної етимології», яке унаочнює добре відомою філологам квазіказкою «Пуськи бяті». Висновки А. Загнітка грунтуються на здобутках петербурзької психолінгвістичної школи, зокрема на працях iз експериментальних методів дослідження словотвірних процесів Л. Сахарного. Психолінгвіст намагався емпіричним шляхом з'ясувати механізми творення слів, зокрема нових, і виявити чинники актуалізації дериваційних зв'язків у мовленні для відтворення готових вербальних зразків й продукування оказіональних.

Розроблювана С. Тогоєвою з 1986 р. психолінгвістична теорія неології безпосередньо апелює до зв'язку дериваційних процесів із мисленням i свідомістю. На жаль, в україністиці лінгвісти наразі не представили подібних досліджень монографічного чи дисертаційного рівня з указаної проблематики, однак на базі Неографічної лабораторії «Неолекс-Рівне» здійснено спробу проаналізувати психологічні засади словотворчості М. Вінграновського. На ширшому мовному матеріалі особливості психолінгвістичних засад деривації торкається білорусист Б. Норман, намагаючись з'ясувати механізми активізації словотвірних процесів у свідомості мовця й слухача. Найбільш вивченим сьогодні як в україністиці, так і в зарубіжних студіях є формування мовленнєвої діяльності, зокрема словотвірної компетенції, в онтогенезі.

Iз огляду на викладене вище можемо констатувати, що психолінгвістичні підходи до вивчення різних аспектів словотворення складно назвати малодослідженою науковою сферою, однак разом із тим простежується брак вітчизняних досліджень монографічного чи дисертаційного рівня, у яких би окреслене коло питань набуло грунтовного, системного й усебічного висвітлення. Пропонований нами аналіз здобутків і перспектив психолінгвістичного параметризування словотвірних процесів - лише окрема спроба узагальнити погляди фахівців на взаємозв'язки між граматикою, мовленнєвою діяльністю, мисленням та свідомістю, що засвідчує потребу в подальшому розробленні вказаного напряму не тільки й не стільки на теоретико-методологічному рівні, скільки на практичному.

\section{Література:}

1. Бодуэн де Куртенэ И. А. Общее языкознание. Избранные труды, Москва: Юрайт, 2017. 343 с. 
2. Вокальчук Г. М., Браун А. І. Лексичні новотвори Миколи Вінграновського 3 погляду психолінгвістики. Словотворчість шістдесятників. Ліна Костенко. Микола Вінграновський : зб. наук. пр. Острог: Вид-во Нац. ун-ту «Острозька акад.», 2010. Вип. 3. С. 97-105.

3. Гумбольдт Вильгельм фон Избранные труды по языкознанию / пер. с нем. яз. под ред. и с предисл. Г.В. Рамишвили, 2. изд. М.: Прогресс, 2000. $396 \mathrm{c}$.

4. Загнітко Анатолій Сучасні лінгвістичні теорії: монографія. Вид. 2-ге, випр. і доп, Донецьк: ДонНУ, 2007. 219 с.

5. Леонтьев А. Н. Избранные психологические произведения: в 2-х т. М.: Книга по Требованию, 2014. Т 1.392 с.

6. Норман Б. Ю. Основы психолингвистики: курс лекций, Минск: БГУ, 2011. $131 \mathrm{c.}$

7. Потебня А. А. Мысль и язык. Избранные работы, Москва: Юрайт, 2019. 238 с.

8. Сахарный Л. В. Психолингвистические аспекты теории словообразования: учебное пособие. Ленинград: ЛГУ, 1985. 97 с.

9. Сосюр Фердінан де. Курс загальної лінгвістики / пер. 3 фр. А. Корнійчук, К. Тищенко, К.: Основи, 1998. 324 с.

10. Тогоева С. И. Психолингвистические проблемы неологии: монография. Тверь: Тверской гос. университет, 2000. 155 с.

11. Шахнарович А. М. Лингвистический эксперимент как метод лингвистического и психолингвистического исследования. Ocновы теории речевой деятельности: коллективная монография / под ред. А. А. Леонтьева. М.: Наука, 1974. С. 129-134.

12. Щерба Л. В. Языковая система и речевая деятельность, изд. 2-е, М.: Едиториал УРСС, 2004. 432 c.

13. Dittrich O. Die Probleme der Sprachpsychologie und ihre gegenwärtigen Lösungsmöglichkeiten, Leipzig: Quelle \& Meyer, 2013. 148 p.

14. Kainz Friedrich Psychologie der Sprache: Bd.II Vergleichendgenetische Sprachpsychologie, Stuttgart: Enke, 1969. 760 p.

15. Pronko N. H. Language and psycholinguistics: a review. Psychological Bulletin. 1946. Vol. 43. P. 189-239. 